\title{
Two New Caffeoyl Threonate Esters from the Leaves of Toxicodendron vernicifluum
}

\author{
Jae Young Jang ${ }^{1}$, Jong Hoon Ahn ${ }^{1}$, Yang Hee Jo ${ }^{1}$, Ayman Turk ${ }^{1}$, So Young Kang ${ }^{2}$, \\ Bang Yeon Hwang', and Mi Kyeong Lee ${ }^{1, *}$ \\ ${ }^{1}$ College of Pharmacy, Chungbuk National University, Cheongju, Korea \\ ${ }^{2}$ Department of Aqualife Medicine, Chonnam National University, Yeosu, Korea
}

\begin{abstract}
Toxicodendron vernicifluum, also called as Rhus verniciflua is a deciduous tree belonging to Anacardiaceae family. Two new caffeoyl threonate esters, rhuseols A (1) and B (2), together with 5-O- $(E)$ caffeoylquinic acid methyl ester (3) were isolated from the leaves of $T$. vernicifluum. The structures of isolated compounds were established by using $1 \mathrm{D}$ and 2D NMR in combination with HR-ESI-MS. Compounds 1 - 3 showed DPPH radical scavenging effects with $\mathrm{IC}_{50}$ values of $47.9,107.8$ and $15.4 \mu \mathrm{M}$, respectively. Taken together, these compounds might contribute to the antioxidant properties of the leaves of $T$. vernicifluum, which will be useful for various oxidative stress mediated diseases.
\end{abstract}

Keywords - Toxicodendron vernicifluum, caffeoyl threonate esters, antioxidant effect

\section{Introduction}

Toxicodendron vernicifluum (Stokes) F.A. Barkley, also called as Rhus verniciflua is a deciduous tree belonging to Anacardiaceae family. It is widely distributed in Asia including Korea and also known as a lacquer tree. All parts of this plant are also used in traditional medicines and exerted diverse biological activities including antioxidant, anticancer, anti-inflammatory and antimicrobial effects have been reported. ${ }^{1-4}$

Plants contain various bioactive substances. These substances are synthesized through biosynthesis, and each plant synthesizes different materials with specific biosynthetic enzymes. This represents the component diversity of each plant, which leads to the diversity of diversity. Differential composition and biological activity depending on the part have been reported by comparative analysis of different parts of plants. ${ }^{5-8}$ For example, tanshinones and phenolic acids are abundant in roots of Salvia miltiorrhiza, whereas flavonoids and triterpenes are abundant in stems and leaves. Our previous study showed the difference of chemical constituents of each part, such as bark, lignum, leaf and fruit using LC-MS-MS and PCA analysis, and this eventually led to differences in

\footnotetext{
*Author for correspondence

Mi Kyeong Lee Ph.D., College of Pharmacy, Chungbuk National

University, Cheongju 28160, Korea

Tel: +82-43-261-2818; E-mail: mklee@chungbuk.ac.kr
}

biological efficacy. ${ }^{9}$ However, most of the studies on $T$. vernicifluum have been done on barks and there is little study on other parts. ${ }^{10-12}$ Leaves are consumed as food, but little has been studied about its ingredients and benefits. This encourage us to investigate about the leaf of T. vernicifluum for wide application. In this study, three phenolic compounds, including two new compounds, were isolated from the leaves of T. vernicifluum and their structure were identified using spectroscopic analyses. Antioxidant efficacy of isolated compounds were also evaluated.

\section{Experimental}

Plant materials - The leaves of $T$. vernicifluum were collected from the farm in Buyeo, Korea in June 2016. After identification by the herbarium of the College of Pharmacy, Chungbuk National University, voucher specimen (CBNU2016-RVF) was deposited in a specimen room of the herbarium. The dried leaves of $T$. vernicifluum $(1.5 \mathrm{~kg})$ were extracted twice with $90 \% \mathrm{MeOH}$. The extract was evaporated under reduced pressure, which yielded the methanol extract $(310 \mathrm{~g})$. The methanol extract was suspended in water and partitioned successively with $n$ hexane, $\mathrm{CH}_{2} \mathrm{Cl}_{2}$ and EtOAc.

Extraction and isolation - The EtOAc fraction (RVE, $4.5 \mathrm{~g}$ ) was chromatographed on a silica gel column chromatography and eluted with the mixture of $\mathrm{CH}_{2} \mathrm{Cl}_{2-}$ 
$\mathrm{MeOH}$ with increasing polarity to give fifteen subfractions (RVE1-RVE15). RVE13 was chromatographed on MPLC (RP-18) and eluted with $\mathrm{MeOH}-\mathrm{H}_{2} \mathrm{O}$ (10:90 to 100:0 gradient) to obtain 13 fractions (RVE13A - RVE13M). Compounds 1 ( $4.6 \mathrm{mg}), 2(4.7 \mathrm{mg})$ and $\mathbf{3}(1.9 \mathrm{mg})$ were purified from RVE13A by Sephadex LH-20 column chromatography eluted with $\mathrm{CH}_{2} \mathrm{Cl}_{2}-\mathrm{MeOH}$ (1:1) and followed by semi-preparative HPLC $\left(\mathrm{MeOH}-\mathrm{H}_{2} \mathrm{O}, 20: 80\right)$.

Rhuseoyl A (1): brown syrup; $[\alpha]_{\mathrm{D}}^{25}+10.4$ (c 0.1 , $\mathrm{MeOH}$ ); UV (MeOH) $\lambda_{\max } 216,326 \mathrm{~nm}$; $\mathrm{IR}_{\max } 3324$, $1654 \mathrm{~cm}^{-1}$; ${ }^{1} \mathrm{H}$ NMR (500 MHz, $\left.\mathrm{CD}_{3} \mathrm{OD}\right)$ and ${ }^{13} \mathrm{C} \mathrm{NMR}$ $\left(\mathrm{CD}_{3} \mathrm{OD}, 100 \mathrm{MHz}\right.$ ), see Table 1; ESI-MS (positive mode) $\mathrm{m} / \mathrm{z} 335[\mathrm{M}+\mathrm{Na}]^{+}$; HR-ESI-MS (positive mode) $\mathrm{m} / \mathrm{z}$ 335.0737 (calcd for $\mathrm{C}_{14} \mathrm{H}_{16} \mathrm{O}_{8} \mathrm{Na} 335.0743$ ).

Rhuseoyl B (2): brown syrup; $[\alpha]_{\mathrm{D}}^{25}+11.9^{\circ}(c$ 0.06, $\mathrm{MeOH}$ ); UV (MeOH) $\lambda_{\max } 217,325 \mathrm{~nm}$; IR $\max _{\max } 3323$, $1654 \mathrm{~cm}^{-1}$; ${ }^{1} \mathrm{H}$ NMR (500 MHz, $\left.\mathrm{CD}_{3} \mathrm{OD}\right)$ and ${ }^{13} \mathrm{C}$ NMR $\left(\mathrm{CD}_{3} \mathrm{OD}, 100 \mathrm{MHz}\right.$ ), see Table 1; ESI-MS (positive mode) $\mathrm{m} / \mathrm{z} 335[\mathrm{M}+\mathrm{Na}]^{+}$; HR-ESI-MS (positive mode) $\mathrm{m} / \mathrm{z}$ 335.0733 (calcd for $\mathrm{C}_{14} \mathrm{H}_{16} \mathrm{O}_{8} \mathrm{Na} 335.0743$ ).

Measurement of antioxidant activity - The antioxidant activity was evaluated by measuring the DPPH radical scavenging activity. Briefly, samples were mixed with freshly prepared DPPH solution. After shaking, the reaction mixtures were stand for $30 \mathrm{~min}$ at room temperature in dark places. The radical scavenging activity was determined by measuring the absorbance at $517 \mathrm{~nm}$. The relative radical scavenging activity (\%) was calculated as [1 - absorbance of solution with sample and DPPH / absorbance of solution with DPPH] $\times 100$.

\section{Results and Discussion}

Investigation on the constituents of $T$. vernicifluum leaves yielded three compounds including two new compounds (Fig. 1).

Compound 1 was purified as brown syrup and its molecular formula was determined as $\mathrm{C}_{14} \mathrm{H}_{16} \mathrm{O}_{8}$ from the HRESI-MS $\left(m / z 335.0737[\mathrm{M}+\mathrm{Na}]^{+}\right.$, calcd for $\mathrm{C}_{14} \mathrm{H}_{16} \mathrm{NaO}_{8}$, 335.0743) and ${ }^{13} \mathrm{C}$ NMR data. The IR spectrum of 1 suggested the presence of hydroxyl $\left(3324 \mathrm{~cm}^{-1}\right)$ and carbonyl $\left(1654 \mathrm{~cm}^{-1}\right)$ functionalities. In the aromatic region of ${ }^{1} \mathrm{H}$ NMR spectrum, signals attributed to $1,3,4,-$ trisubstituted aromatic ring and a double bond in transconfiguration were observed at $\left[\delta_{\mathrm{H}} 7.06(1 \mathrm{H}, \mathrm{d}, J=2.4\right.$ Hz, H-2'), 6.79 (1H, d, $\left.J=8.0 \mathrm{~Hz}, \mathrm{H}-5^{\prime}\right), 6.97(1 \mathrm{H}, \mathrm{dd}$, $\left.\left.J=8.0,2.4 \mathrm{~Hz}, \mathrm{H}-6^{\prime}\right)\right]$ and $\left[\delta_{\mathrm{H}} 7.61(1 \mathrm{H}, \mathrm{d}, J=16.0 \mathrm{~Hz}\right.$, H-7'), $6.27\left(1 \mathrm{H}, \mathrm{d}, J=16.0 \mathrm{~Hz}, \mathrm{H}-8^{\prime}\right)$ ], respectively. The corresponding carbon signals at $\left[\delta_{\mathrm{C}} 126.3\left(\mathrm{C}-1^{\prime}\right), 113.7\right.$ (C-2'), 145.4 (C-3'), 148.3 (C-4'), 115.1 (C-5'), 121.7 (C$\left.\left.6^{\prime}\right)\right]$ and $\left[\delta_{\mathrm{C}} 146.2\left(\mathrm{C}-7^{\prime}\right), 113.2\left(\mathrm{C}-8^{\prime}\right)\right]$ in HSQC spectrum together with carbonyl signal at $\delta_{\mathrm{C}} 166.8\left(\mathrm{C}-9^{\prime}\right)$ clearly showed the presence of trans-caffeoyl moiety. Besides aforementioned signals, the ${ }^{1} \mathrm{H}$ NMR spectrum revealed the presence of a methylene at $\delta_{\mathrm{H}} 3.75(1 \mathrm{H}, \mathrm{dd}, J=11.2$, $6.8 \mathrm{~Hz}, \mathrm{H}-1 \mathrm{a}), 3.83$ (1H, dd, $J=11.2,6.4 \mathrm{~Hz}, \mathrm{H}-1 \mathrm{~b})$, two oxymethines at $\delta_{\mathrm{H}} 5.30(1 \mathrm{H}$, ddd, $J=6.8,6.4,2.4 \mathrm{~Hz}, \mathrm{H}-$ 2) and $\delta_{\mathrm{H}} 4.52(1 \mathrm{H}, \mathrm{d}, J=2.4 \mathrm{~Hz}, \mathrm{H}-3)$ and a methoxy group at $\delta_{\mathrm{H}} 3.74\left(3 \mathrm{H}, \mathrm{s}, \mathrm{OCH}_{3}\right)$. The correlations between $\mathrm{H}-1$ and $\mathrm{H}-2, \mathrm{H}-2$ and $\mathrm{H}-3$ in ${ }^{1} \mathrm{H}-{ }^{1} \mathrm{H}$ COSY spectrum suggested the presence of $-\mathrm{CH}_{2}-\mathrm{C}(\mathrm{OH})-\mathrm{C}(\mathrm{OH})$ - in $\mathbf{1}$. The corresponding carbon signals at $\delta_{\mathrm{C}} 59.5(\mathrm{C}-1), 74.3(\mathrm{C}-2)$,

Table 1. NMR spectroscopic data for compounds $\mathbf{1}$ and $\mathbf{2}\left(\mathrm{CD}_{3} \mathrm{OD}\right)$.

\begin{tabular}{|c|c|c|c|c|}
\hline & 1 & & 2 & \\
\hline & $\delta_{\mathrm{H}}$ & $\delta_{\mathrm{C}}$ & $\delta_{\mathrm{H}}$ & $\delta_{\mathrm{C}}$ \\
\hline 1 & $\begin{array}{l}3.75(\mathrm{dd}, 11.2,6.8) \\
3.83(\mathrm{dd}, 11.2,6.4)\end{array}$ & 59.5 & $\begin{array}{c}4.27 \mathrm{brs} \\
4.29(\mathrm{~d}, 6.4)\end{array}$ & 64.3 \\
\hline 2 & $5.30(\mathrm{ddd}, 6.8,6.4,2.4)$ & 74.3 & $4.23 \mathrm{~m}$ & 70.0 \\
\hline 3 & $4.52(\mathrm{~d}, 2.4)$ & 69.2 & $4.32(\mathrm{~d}, 2.4)$ & 71.2 \\
\hline 4 & & 172.8 & & 173.1 \\
\hline $1^{\prime}$ & & 126.3 & & 126.3 \\
\hline $2^{\prime}$ & $7.06(\mathrm{~d}, 2.4)$ & 113.7 & $7.06(\mathrm{~d}, 2.4)$ & 113.7 \\
\hline $3^{\prime}$ & & 145.4 & & 145.4 \\
\hline $4^{\prime}$ & & 148.3 & & 148.3 \\
\hline $5^{\prime}$ & $6.79(\mathrm{~d}, 8.0)$ & 115.1 & $6.79(\mathrm{~d}, 8.0)$ & 115.1 \\
\hline $6^{\prime}$ & $6.97(\mathrm{dd}, 8.0,2.4)$ & 121.7 & $6.97(\mathrm{dd}, 8.0,2.4)$ & 121.6 \\
\hline $7^{\prime}$ & $7.61(\mathrm{~d}, 16.0)$ & 146.2 & $7.61(\mathrm{~d}, 16.0)$ & 145.9 \\
\hline $8^{\prime}$ & $6.27(\mathrm{~d}, 16.0)$ & 113.2 & $6.27(\mathrm{~d}, 16.0)$ & 113.7 \\
\hline $9^{\prime}$ & & 166.8 & & 167.5 \\
\hline $\mathrm{OCH}_{3}$ & $3.74 \mathrm{~s}$ & 51.3 & 3.74 & 51.2 \\
\hline
\end{tabular}


<smiles>COC(=O)[C@H](O)[C@H](CO)OC(=O)/C=C/c1ccc(O)c(O)c1</smiles><smiles>COC(=O)[C@H](O)[C@@H](O)COC(=O)/C=C/c1ccc(O)c(O)c1</smiles><smiles>COC(=O)[C@]1(O)C[C@@H](O)[C@H](O)[C@H](OC(=O)/C=C/c2ccc(O)c(O)c2)C1</smiles>

Fig. 1. Chemical structures of compounds 1 - 3.

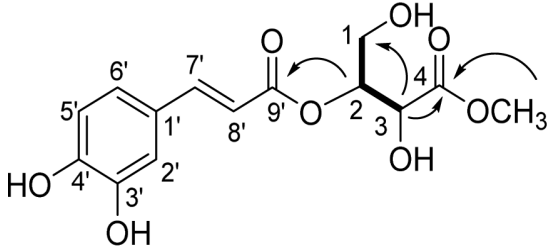

1<smiles>CCCC1(O)CCC2(OC(=O)C=Cc3ccc(O)c(O)c3)CC(C)(C(=O)OC)C(O)C12</smiles>

2

Fig. 2. Chemical structures and key ${ }^{1} \mathrm{H}-{ }^{1} \mathrm{H}$ COSY $(-)$ and $\mathrm{HMBC}(\rightarrow)$ correlations of compounds $\mathbf{1}$ and $\mathbf{2}$.

$69.2(\mathrm{C}-3), 51.3\left(\mathrm{OCH}_{3}\right)$, and carbonyl signal at $\delta_{\mathrm{C}} 172.8$ in the HSQC spectrum together with $\mathrm{HMBC}$ correlations of $\mathrm{H}-1$ to $\mathrm{C}-2$ and $\mathrm{C}-3, \mathrm{H}-3$ to $\mathrm{C}-4$ and positive value of optical rotation suggested the presence of threonic acid. ${ }^{13}$ The HMBC correlations from $\delta_{\mathrm{H}} 3.74\left(3 \mathrm{H}, \mathrm{s}, \mathrm{OCH}_{3}\right)$ to $\delta_{\mathrm{C}} 172.8$ (C-4) determined the position of a methoxy group (Fig. 2). The connection between a threonyl group and a caffeoyl moiety was assigned by the HMBC correlation from H-2 to C-9', a carbonyl of caffeoyl moiety. Taken together, compound $\mathbf{1}$ was determined as shown in Fig. 1 and named rhuseoyl A.

Compound $\mathbf{2}$ was purified as brown syrup and same molecular formula of $\mathrm{C}_{14} \mathrm{H}_{16} \mathrm{O}_{8}$ was deduced from a pseudomolecular ion $[\mathrm{M}+\mathrm{Na}]^{+}$of $\mathrm{m} / z 335.0733$ at the HRESI-MS analysis. Comparison of the ${ }^{1} \mathrm{H}$ and ${ }^{13} \mathrm{C}$ data of $\mathbf{2}$ with those of $\mathbf{1}$ disclosed that $\mathbf{2}$ also has transcaffeoyl acid moiety. The presence of threonic acid was suggested by the signals at $\delta_{\mathrm{H}} 4.27(1 \mathrm{H}$, brs, H-1a), 4.29 $(1 \mathrm{H}, \mathrm{d}, J=6.4 \mathrm{~Hz}, \mathrm{H}-1 \mathrm{~b}), 4.23(1 \mathrm{H}, \mathrm{m}, \mathrm{H}-2)$ and 4.32 $(1 \mathrm{H}, \mathrm{d}, J=2.4 \mathrm{~Hz}, \mathrm{H}-3)$, displaying ${ }^{1} \mathrm{H}-{ }^{1} \mathrm{H}$ COSY correlations between $\mathrm{H}-1$ and $\mathrm{H}-2, \mathrm{H}-2$ and $\mathrm{H}-3$ as in $\mathbf{1}$. Further examination of NMR data, however, disclosed the differences in the chemical shifts of $\mathrm{H}-1, \mathrm{H}-2$ and $\mathrm{H}-3$. The chemical shift of $\mathrm{H}-1$ was downfield shifted from $\delta_{\mathrm{H}}$ 3.75 and 3.83 to $\delta_{\mathrm{H}} 4.27$ and 4.29 , whereas that of $\mathrm{H}-2$ was upfield shifted from $\delta_{\mathrm{H}} 5.30$ to $\delta_{\mathrm{H}} 4.27$ and 4.23. In addition, $\mathrm{HMBC}$ correlation from $\mathrm{H}-1$ to $\mathrm{C}-9^{\prime}$ was observed in 2, instead of correlation from H-2 to C-9' in $\mathbf{1}$ (Fig. 2). Therefore, 2 was suggested to differ from $\mathbf{1}$ in the linkage between caffeoyl acid and threonic acid as carbonyl of caffeoyl moiety was connected to C-1 of threonic acid. Taken together, compound $\mathbf{2}$ was determined as shown and named rhuseoyl B.

Compound 3 was identified as 5-O-(E)-caffeoylquinic acid methyl ester by the spectroscopic data analysis and comparison with those of published values. ${ }^{14}$

Evaluation of biological activity of isolated compounds suggested the DPPH radical scavenging effects of compounds $\mathbf{1}$ - $\mathbf{3}$ with $\mathrm{IC}_{50}$ values of $47.9,107.8$ and $15.4 \mu \mathrm{M}$, respectively. Taken together, our present study suggested that these compounds might contribute to the antioxidant properties of the leaves of $T$. vernicifluum, which will be useful for various oxidative stress mediated diseases.

\section{Acknowledgements}

This work was supported by Basic Science Research Program (2018R1D1A1A09082643) through the National Research Foundation of Korea. 


\section{References}

(1) Kim, J. S.; Kwon, Y. S.; Chun, W. J.; Kim, T. Y.; Sun, J.; Yu, C. Y.; Kim, M. J. Food Chem. 2010, 120, 539-543.

(2) Lee, S. O.; Kim, S. J.; Kim, J. S.; Ji, H.; Lee, E. O.; Lee, H. J. BMC Complement. Altern. Med. 2018, 18, 242.

(3) Park, K. Y.; Jung, G. O.; Lee, K. T.; Choi, J.; Choi, M. Y.; Kim, G. T.; Jung, H. J.; Park, H. J. J. Ethnopharmacol. 2004, 90, 73-79.

(4) Lee, J. H.; Lee, H. J.; Lee, H. J.; Choi, W. C.; Yoon, S. W.; Ko, S. G.; Ahn, K. S.; Choi, S. H.; Ahn, K. S.; Lieske, J. C.; Kim, S. H. Phytomedicine 2009, 16, 188-197.

(5) Agu, K. C.; Okolie, P. N. Food Sci. Nutr. 2017, 5, 1029-1036.

(6) Zeng, H.; Su, S.; Xiang, X.; Sha, X.; Zhu, Z.; Wang, Y.; Guo, S.; Yan, H.; Qian, D.; Duan, J. Molecules 2017, 22, E771.

(7) Wei, J. N.; Liu, Z. H.; Zhao, Y. P.; Zhao, L. L.; Xue, T. K.; Lan, Q. K. Food Chem. 2019, 286, 260-267.

(8) Pompermaier, L.; Marzocco, S.; Adesso, S.; Monizi, M.; Schwaiger, S.; Neinhuis, C.; Stuppner, H.; Lautenschläger, T. J. Ethnopharmacol. 2018, 216, 26-36.
(9) Jang, J. Y.; Shin, H.; Lim, J. W.; Ahn, J. H.; Jo, Y. H.; Lee, K. Y.; Hwang, B. Y.; Jung, S. J.; Kang, S. Y.; Lee, M. K. PLoS One 2018, 13, e0200257.

(10) Kim, K. H.; Moon, E.; Choi, S. U.; Kim, S. Y.; Lee, K. R. Phytochemistry 2013, 92, 113-121.

(11) Chen, H.; Wang, C.; Ye, J.; Zhou, H.; Yuan, J. Nat. Prod. Res. 2014, 28, 496-499.

(12) Kang, S. Y. J. Fish Pathol. 2005, 18, 227-237.

(13) Kuczkowiak, U.; Perereit, F.; Nahrstedt, A. Sci. Pharm. 2014, 82, 835-846.

(14) Silva, D. B.; Okano, L. T.; Lopes, N. P.; de Oliveira, D. C. R. Phytochemisty 2013, 96, 418-422.

Received October 27, 2019

Revised December 2, 2019

Accepted December 2, 2019 